\title{
PH.D.-AFHANDLING OM "RELIGIØS PLURALISME FRA ET MAGTPERSPEKTIV"
}

Ved et offentligt forsvar for afhandlingen Out of Many, One. A theoretical and empirical study of religious pluralism in Denmark from a perspective of power, indleveret til bedømmelse ved Det Teologiske Fakultet, Aarhus Universitet, erhvervede Lene Maria van der Aa Kühle ph.d.-graden samme sted den 24. september 2004. Bedømmelsesudvalget bestod af formand, professor Per Ingesman, Aarhus Universitet, professor Pål Repstad, Høgskolen i Agder, og professor James A. Beckford, University of Warwick. Nedenfor bringes en redigeret udgave af Lene Kühles indledning og resume ved forsvaret fulgt af en redigeret og oversat udgave af James A. Beckfords indleg ved samme lejlighed.

\section{Indledning og resumé ved Lene Maria van der Aa Kühle}

Vi lever i dag i et pluralistisk samfund, hvor vi også hele tiden påvirkes af mange ikkekristne holdninger: nyreligiøsitet og fremmede religioner, der til stadighed forsøger at få os bort fra den eneste sande Gud og troen på ham, og det budskab, som Bibelen giver os om ham og hans søn, Jesus Kristus. ${ }^{1}$

Hvis man vil have et ordentligt integrationsforløb, hvis man vil have et velfungerende samfund, er det at kende sine rødder, sit fundament og sin identitet jo væsentligt, så vi ikke bare bliver til flagrende mennesker i en pluralistisk, pragmatisk tid, hvor alle nærmest kan mene, hvad de selv vil. ${ }^{2}$

De ovenstående citater peger på, at (religiøs) pluralisme er blevet et vilkår i offentlige debatter om religion, immigration, integration, kulturel/religiøs mangfoldighed og det multi-kulturelle samfund. Samtidig har pluralisme siden 1960'erne været et centralt begreb i religionssociologien, hvor det har været brugt som betegnelse for den situation, at forskellige religioner opfatter sig som konkurrerende, og at forholdet mellem disse og 'de religiøse' forbrugere tager form af et religiøst marked. Min afhandling har et dobbelt formål. For det første diskuterer jeg forskellige definitioner af pluralisme med det formål at få redskaber til at fremsætte en definition af pluralisme i relation til religion ('religiøs pluralisme'), som - så vidt muligt - kan forene brugen af begrebet pluralisme i forskellige sammenhænge. For det andet afprøves dette begrebs nyttighed i en empirisk

\footnotetext{
${ }^{1}$ www.kristen.dk; præsentation af Indre Missions radio.

${ }^{2}$ Brian Mikkelsen, 5. april 2005, Første behandling af lovforslag nr. L 178: Forslag til lov om ændring af lov om folkeskolen (Ophævelse af mulighed for fritagelse for religionsundervisning).
} 
undersøgelse af, hvordan 'religiøs pluralisme' har udviklet sig i Danmark fra Grundloven til i dag.

Den teoretiske del af argumentationen falder i to dele. Kapitel 2 indeholder først en diskussion af en række forskellige måder, hvorpå begrebet religiøs pluralisme er blevet benyttet - empirisk og teoretisk - inden for religionssociologien. Konklusionen er, at religiøs pluralisme er blevet anvendt forskelligt dels pga. forskellige opfattelser af, hvad religion er, dels fordi man har trukket på forskellige forståelser af, hvad pluralisme er, afhængig af hvilken tradition (filosofisk, antropologisk eller politologisk) den enkelte religionssociolog har været inspireret af. På den måde har der været ikke én, men mange forståelser af, hvad religiøs pluralisme er. Anden del af kapitel indeholder derfor et forsøg på at fremsætte en række kriterier for, hvordan en definition af religiøs pluralisme kan se ud. Et af disse kriterier er, at religiøs pluralisme med fordel kan forstås som en forlængelse af en mere generel pluralisme. Et andet kriterium er, at det er hensigtsmæssigt at forstå religiøs pluralisme som andet og mere end den blotte eksistens af forskellige religioner - som man kunne kalde mangfoldighed (diversity). Ligeledes fremhæver jeg, at man bør begrænse forståelse af religiøs pluralisme til at angå (men altså ikke at være det samme som) religiøs mangfoldighed og ikke udbrede begrebets betydning til fx 'religiøs fragmentering' eller 'religion a la carte', som man undertiden ser det.

\section{Religiøs pluralisme i et magtperspektiv}

De fire sidste kriterier hører sammen og er mindre generelle og mere relateret til mit konkrete projekt. For det første har mange definitioner af pluralisme har været normative snarere end deskriptive. Det er der for så vidt ikke noget galt $\mathrm{i}$; men mit udgangspunkt er det pragmatiske, at en normativ tilgang til religiøs pluralisme i mindre grad er velegnet som udgangspunkt for den givne, konkrete problemstilling: kan man empirisk argumentere for, at fx Danmark er religiøst pluralistisk? Det, jeg er interesseret i, er altså den faktiske udbredelse af religiøs pluralisme, ikke spørgsmålet om hvorvidt det er mere eller mindre godt for samfundet, demokratiet eller individet. Det er klart, at den empiriske undersøgelse kan tænkes at vise, fx, at religiøs pluralisme kan virke fremmende på demokratiet eller ødelæggende for samfundets sammenhængskraft. I sådanne tilfælde ville man kunne sige, at religiøs pluralisme er henholdsvis en god eller en dårlig ting under den forudsætning, at demokrati eller sammenhængskraft er positive værdier). Påstanden er altså ikke, at definitionen af religiøs pluralisme ikke kan have normative konsekvenser, men kun, at jeg forsøger ikke at indbygge dem i selve definitionen. Dette udgangspunkt leder til de tre sidste kriterier. For det første er konsekvensen af valget af en deskriptiv definition som antydet, at definitionen ikke på forhånd bør knyttes bestemte historiske (fx moderne), geografiske (fx vestlige) eller juridiske (fx demokratiske) omstændigheder. Jeg mener ikke hermed, at moderne, vestlige og demokratiske samfund ikke er eller kan være religiøs pluralistiske, men at jeg om udgangspunkt vil lade det stå åbent for empirisk efterprøvelse, om de faktisk er det. Da ideen med en deskriptiv definition er at kunne undersøge eksistensen af pluralisme empirisk, vil jeg 
for det andet kræve, at definition af religiøs pluralisme skal kunne anvendes i en konkret empirisk sammenhæng. Det har for det tredje den konsekvens, at definitionen bør hente sin inspiration i antropologien og politologien snarere end i filosofien eller teologien. Fremsættelsen af kriterierne munder ud i en foreløbig definition af religiøs pluralisme, særligt inspireret af politologen Robert A. Dahl, som forstod (politisk) pluralisme som en fordeling af magt mellem forskellige partier. Religiøs pluralisme kan ud fra dette forsøgsvist forstås som en tilstand, hvor den religiøse magt er fordelt mellem forskellige religiøse grupperinger eller institutioner.

\section{Bourdieus tilgang til religion}

Kapitel 3 indeholder anden del af det teoretiske argument, nemlig et forsøg på at specificere denne definition ved at knytte den til den franske sociolog Pierre Bourdieus definition af et 'felt'. Et felt er en struktur af relationer mellem positioner, hvis forhold sættes af fordelingen af 'kapital', i betydningen 'potentiel magt'. Felter er samtidig arenaer for magtkampe om indholdet og værdisætningen af de forskellige typer af kapital, hvor chancen for et bestemt udfald bestemmes af, hvordan tidligere kampe har fastlagt mængden, indholdet og værdien af forskellige former for kapital. Bourdieus magtbegreb har den fordel i forhold til Dahls magtbegreb, at magt både knyttes til enkeltpersoners handlinger og til institutionelle og organisatoriske strukturer. Samtidig forstås magt både som 'magt til' og som 'magt over'. Dermed betragtes magt som en nødvendig del af menneskelig handlen, uden at magten dog reduceres til individets beslutninger om at handle.

Selv om Bourdieu kun har behandlet det religiøse felts form og logik i nogle få artikler, er grundtrækkene af en magt-teoretisk tilgang klare nok. Det religiøse felt udspændes ifølge Bourdieu dels af relationer mellem lægfolk og religiøse eksperter, dels af relationerne mellem de religiøse eksperter indbyrdes. Religiøse felter vil derfor kendetegnes af kampe om, hvad der kan gælde som fx legitim kristendom og om magt til at sætte denne opfattelse igennem i forhold til lægfolket. Bourdieus fremstilling af det religiøse felt er blevet kritiseret for at være meget 'katolsk', dvs. orienteret mod en situation med et klart skel mellem præster og lægfolk og en situation, hvor én kirke har en monopolagtig status. I min afhandling argumenterer jeg imidlertid for, at Bourdieu ikke har fremsat nogen generel teori om religion, men at hans artikler om religion $\mathrm{i}$ stedet bør forstås som en fremstilling af fremkomsten af et specifikt religiøst felt, nemlig den katolske kirke i Vesteuropa. Dette betyder ikke, at hans begreber skulle være uanvendelige $\mathrm{i}$ forhold til andre religiøse situationer, men at man, når man læser Bourdieu, skal være opmærksom på, hvornår han taler empirisk og hvornår han taler teoretisk. Bourdieus interesse i religion var i høj grad en interesse for magtforholdene inden for den katolske kirke. Hvis Bourdieus begreb om felter skal kunne bruges i andre, også ikke-katolsk-dominerede, moderne samfund, kan det være nødvendigt at operere med muligheden for flere forskellige religiøse felter. Derudover introducerer jeg i afhandlingen 'det religiøse magtfelt' som en underafdeling af det generelle magtfelt. Det generelle magtfelt er for Bourdieu et metafelt, hvor der ikke (som i andre felter) 
kæmpes om, hvilket indhold den pågældende kapital skal have, men om 'vekselkursen' mellem forskellige typer kapital. Kort fortalt vil det, der er på spil i det religiøse magtfelt, ikke være, hvem der skal tegne (dvs. repræsentere, regulere og redigere de enkelte religioner), men hvordan de forskellige religioner forholder sig til hinanden. Det religiøse magtfelt handler derfor om, hvilke religioner der opfattes som gode samarbejds- og diskussionspartnere og hvilke man ikke vil være i stue med. Hvor kampene i de religiøse felter handler om, hvad der kan anses for væsentlige dele af de enkelte religioner, handler kampene i det religiøse magtfelt om, hvilke religioner, der kan opfattes som legitime, og hvad der i det hele taget kan eller skal betragtes som religion.

Bourdieus begreb om felter benyttes til at omformulere definitionen af religiøse pluralisme til eksistensen af et religiøst magtfelt i betydningen af et specifikt felt, hvori 'vekselkursen' mellem forskellige religiøse kapitaler fastsættes. Denne definition af religiøs pluralisme ses at opfylde alle de ovennævnte kriterier, hvor det specielt er væsentligt at fremhæve, at denne definition af religiøs pluralisme ikke giver begrebet en normativ karakter, og at religiøs pluralisme ikke bindes til fx religionsfrihed. Hermed er der ikke på forhånd draget konklusioner om begrebets forhold til formelle juridiske eller politiske begreber; men empiriske studier kan naturligvis påvise, at en sådan forbindelse findes.

\section{Udviklingen af religiøs pluralisme i Danmark}

I kapitel 4 og 5 afprøves anvendeligheden af den ovennævnte definition af religiøs pluralisme i praksis. Kapitel 4 indeholder en analyse af opkomsten og udviklingen af et religiøst magtfelt i (nationalstaten) Danmark siden Grundloven. Udviklingen kan siges at forløbe i fire faser. Kirkehistorikere har understreget, at den evangelisk-lutherske kirke i Danmark før Grundloven af 1849 ikke udgjorde en 'kirke' i betydningen 'en selvstændig organisation'. Dette argument benyttes til at argumentere for, at den evangelisk-lutherske kirke i det før-konstitutionelle Danmark ikke udgjorde et selvstændigt felt adskilt fra staten, og da relationer mellem de tre 'tolererede' religioner: katolicisme, jødedom og reformeret kristendom, stort set synes ikke-eksisterende, konkluderes det, at der ikke fandtes et religiøst magtfelt i Danmark før Grundloven, og at Danmark derfor ikke var religiøst pluralistisk. $§ 80$ i 1849-grundloven (§ 66 i 1953grundloven) siger, at folkekirkens forfatning skal ordnes ved lov. Denne paragraf havde til formål at etablere folkekirken som et selvstændigt felt. Selvom denne paragraf aldrig er blevet indfriet, opnåede folkekirken imidlertid efter 1849 en sådan (delvis) selvstændighed, at den kan betegnes som et selvstændigt felt. I den anden periode (dvs. den første tid efter Grundloven) præges relationerne mellem de religiøse grupper i Danmark imidlertid af konkurrence om at vinde lægfolket for en bestemt variant af kristendommen og ikke mindst af stridigheder om, hvor grænserne for folkekirken lå. Grundtvig var villig til at inkludere bl.a. baptisterne i folkekirken; men udfaldet af kampene var som bekendt, at baptisterne, mormonerne og unitarerne ${ }^{3}$ kom til at stå

\footnotetext{
${ }^{3}$ Unitarisk Trossamfund vurderes at stå uden for folkekirken ved en højesteretsdom i 1908.
} 
uden for folkekirken, mens fx Indre Mission forblev inden for folkekirkens rammer. Frelsens Hær og Missionsforbundet valgte begge som udgangspunkt en position på kanten af folkekirken. Selvom kampene ikke i snæver forstand finder sted inden for folkekirken, er det imidlertid i bred forstand folkekirkens lægfolk og folkekirkens selvforståelse, der har været i centrum. Det relevante felt er derfor snarere et religiøst felt (dvs. hvor det er kampen om lægfolkenes gunst, der er central) end et religiøst magtfelt (der angår relationerne mellem de forskellige religioner).

Fra 1930'erne og 1940'erne skifter kampene imidlertid karakter, og med dannelsen af forskellige fælleskirkelige og økumeniske organisationer indtræder relationerne mellem en lille gruppe frikirker i den tredje fase. Det betyder ikke, at man holder op med at missionere eller at konkurrere om medlemmerne; men der opstår en øget forståelse af, at hvis man vil opnå indflydelse i samfundet, må man samarbejde snarere end at bekæmpe hinanden. Men det er ikke alle, der vil samarbejde, og det er ikke alle, som man vil samarbejde med, så med samarbejdet opstår også kategoriseringer og positioneringer af religioner. Det felt, som hermed opstår, er et egentligt religiøst magtfelt. Fra begyndelsen af 1990'erne sætter den fjerde fase ind. Denne fase er karakteriseret dels ved opkomsten af et nyt 'muslimsk felt', kendetegnet ved en kamp om autoritet $\mathrm{og}$ en mangel på repræsentativ magt (i betydningen magt til at tale på vegne af), og dels ved fremkomsten af et nyt statsligt system af anerkendelse/godkendelse af trossamfund. Selve systemet med anerkendelse går tilbage til 1849-grundloven; men først fra 1990'erne tillægges systemet en sådan klassificerende og kategoriserende magt, at man kan tale om fremkomsten af et religiøst magtfelt, centreret om de anerkendte/godkendte trossamfund. Støttet af etableringen af nye økumeniske og fælleskirkelige organisationer er det frikirkelige magtfelt blevet erstattet af et bredere, religiøst magtfelt med nye inklusions- og eksklusionsmekanismer og med mulige 'eksistensbetingelser' for de religiøse grupper. I forhold til begrebet religiøs pluralisme konkluderes det, at Danmark er et religiøst, pluralistisk samfund og har været det i cirka 70-80 år, men at religiøs pluralisme er i konstant forandring. Det, der er karakteristisk for den nye religiøse pluralisme, er den direkte rolle, som staten har i at opstille de kategorier, hvorudfra det religiøse magtfelt opererer.

\section{Religion i fængslet}

Kapitel 5 indeholder afhandlingens anden 'case', nemlig en undersøgelse af religiøs pluralisme i forhold til det 'samfund', som de danske fængsler udgør. De betingelser, hvorpå 'religion i fængslet' eksisterer, adskiller sig på forskellige måder fra betingelserne i 'det frie samfund': Fængslerne er langt mere religiøst mangfoldige (i nogle fængsler kan andelen af muslimer være 20-30 \%), mens grænserne mellem de forskellige religioner synes langt mindre vigtige $\mathrm{i}$ den forstand, at det ikke er ualmindeligt, at $\mathrm{fx}$ muslimer deltager i alle aspekter af den offentlige, folkekirkelige religiøsitet, inklusiv at synge $\mathrm{i}$ kirkekoret og at gå til alters. Omvendelser mellem kristendom og islam i fængslet er dog få. Langt op i det 19. århundrede fastholdt man et forbud mod omvendelser i fængslet, og selvom det i dag ikke er forbudt, er det de færreste fængsels- 
præster, der er begejstrede for indsatte, der ønsker at omvende sig. De fleste opfordrer i stedet den indsatte til at vente med beslutningen, til de igen indgår i det fri samfund. En anden markant forskel i forhold til samfundet uden for fængslet er eksistensen af fængselspræster, betalt af Justitsministeriet (der er dog også nogle præster betalt af Kirkeministeriet), og af fængselsimamer, ligeledes aflønnet af Justitsministeriet. Samtidig er det blevet indrettet flere fængselsmoskeer. På trods af dette er det tvivlsomt, hvorvidt fængselssystemet kan betegnes som religiøst pluralistisk. I de fleste fængsler anses fængselspræsten for lederen af 'det religiøse', og det er ofte op til hans eller hendes individuelle vurdering, hvad der kan tillades af forskellige offentlige religiøse aktiviteter, men som oftest også op til hans/hendes personlige engagement, om der overhovedet bliver arrangeret noget. Det er således karakteristisk, at en fængselspræst påtog sig at køre de indsatte muslimer til bøn i en nærliggende moske; men da hun ikke længere havde tid til dette, ophørte denne service. På den vis udgør felterne i fængslerne snarere religiøse felter end religiøse magtfelter.

Afhandlingens konklusion er, at forståelsen af religiøs pluralisme som eksistensen af et religiøst magtfelt er en frugtbar tilgang til religiøs pluralisme. På det empiriske plan kan det konkluderes, at Danmark siden 1920'erne har været religiøst pluralistisk, men at denne pluralisme i begyndelsen udelukkende vedrørte en mindre gruppe af frikirker. Først fra 1990'erne ser vi en mere omfattende religiøs pluralisme, selvom bl.a. den danske folkekirke og de muslimske grupperinger i Danmark kun i mindre grad er involveret $\mathrm{i}$ den. I de danske fængsler ser vi en udvikling i retning af en anden type pluralisme, opbygget omkring netop disse to aktører, og udviklingen af denne er koncentreret om nogle bestemte fængsler og endnu blot netop begyndt. Eksemplet med fængslerne viser dog, at spørgsmålet om, hvorvidt Danmark er religiøst pluralistisk, ikke kan besvares, med mindre man undersøger alle de felter, hvor religion spiller en rolle. I denne afhandling behandles ét felt, nemlig fængslet; men også fx sundhedssystemet, undervisningssystemet og militæret bør undersøges, før en endelig konklusion kan drages.

\section{Indlæg ved James A. Beckford}

Gode ph.d.-afhandlinger kan kendes på, at de rejser interessante spørgsmål. Det er indlysende, at afhandlinger også skal opfylde andre kriterier; men læseren vil sandsynligvis få det mest gunstige indtryk af ideer, som med succes udfordrer vedtagne antagelser. Dette kan opnås på mange forskellige måder, som peger på en ph.d.kandidats nye indsigter i empiri, begreber, teorier og problemer. Lene Kühles afhandling om religiøs pluralisme i Danmark rejste så mange tankevækkende spørgsmål for mig, at et skriftligt svar syntes at være på sin plads.

Mit formål her er ikke at gentage de kritiske bemærkninger, som Lene Kühles bedømmelsesudvalg kom med, men at diskutere de bredere perspektiver, som hendes arbejder åbner. Det er mit synspunkt, at disse spørgsmål er af relevans både teoretisk og 
empirisk for mange religionssociologer. Jeg vil derfor diskutere udvalgte elementer, som relaterer sig til en bred vifte af aktuelle emner i studiet af religion som et socialt fænomen.

\section{Danmark og pluralisme i religionen}

Selvom fokuset i Lene Kühles afhandling - væksten i den religiøse pluralisme i Danmark - umiddelbart kan synes snævert, åbner hendes tilgangsvinkel for teoretiske og begrebsmæssige spørgsmål, som overskrider emnet i snævrere forstand. Det betyder ikke, at den langsomme fremkomst af institutioner og praksiser, som røber tolerance og respekt for religiøse minoriteter i Danmark fra midten af det nittende århundrede, ikke er interessant i sig selv. Tværtimod fremstår den danske folkekirke som en særlig interessant organisation i det senmoderne samfund, fordi den er vedblevet med at være en uløselig del af den danske stat. Kirke-stat-relationer er sandsynligvis tættere i Danmark end i noget andet europæisk land. Dette er medvirkende til at gøre fremkomsten af pluralisme særlig omstridt på et tidspunkt, hvor religiøs mangfoldighed er voksende, såvel blandt danskere som blandt nylige migranter til landet.

Diskussionen om religiøs pluralisme i Danmark sætter også spørgsmålstegn ved udbredte antagelser om adskillelsen af religion og stat i de europæiske lande. Det viser navnlig det tvivlsomme i den antagelse, som især er almindelig blandt samfundsforskere og jurister fra lande, hvor katolicisme var eller er den dominerende religion, at stater i nutiden nødvendigvis må være sekulære organisationer. Til eksempel hævder Claude Lefort, at "politiske institutioner for længst er blevet adskilt fra religiøse institutioner" (1986, 253). Tilsvarende argumenterer Jean-Paul Willaime for, at "[ $t]$ he new age of politics is a new stage in the secularisation of politics. It is not only the emancipation of politics from religious tutelage (that is to say, an internal secularisation of politics); but it is also a secularisation of politics itself" (under udgivelse, 80 ).

Disse skråsikre påstande om europæiske staters hævdede sekulære natur yder slet ikke retfærdighed over for situationen i lande som Storbritannien, Tyskland og flere af de nordiske lande, hvor statslige organer på visse niveauer vedbliver med at være tæt sammenknyttede med ledende religiøse organisationer. Dette er på linie med Silvio Ferraris påstand om, at selv tilsyneladende sekulære stater har bibeholdt udvalgte relationer med etablerede kirker. Lene Kühles analyse af de historiske faktorer, der forhindrede den danske folkekirke i at ophøre med at være et organ for den danske stat, repræsenterer en velfunderet udfordring af problematiske antagelser om den moderne stats såkaldte sekularisme.

\footnotetext{
1 "Les institutions politiques se sont depuis longtemps scindées des institutions religieuses".
} 


\section{Magt og religion}

Med få undtagelser ${ }^{2}$ har religionssociologer kun i begrænset omfang rettet opmærksomheden mod magt som en dimension af religion eller som del af de sociale sammenhænge, hvor religion praktiseres. Det er for mig at se særlig slående, at sociologiske redegørelser for pluralisme i religion har en tendens til at fokusere på filosofiske og morale begreber om fx tolerance uden at analysere de - ofte voldelige - magtkampe, som nogle steder var baggrunden for deres indførelse. Pluralismens idehistorie er givetvis veludforsket; men de konflikter og magtkampe, der var med til at skabe disse ideer, er mindre godt forstået. Lene Kühles afhandling insisterer på vigtigheden af magtkampe for religionens udvikling i Danmark i moderne tid og yder derigennem en nyttig påmindelse om religionens evne til at blive et stridsspørgsmål også på tidspunkter, hvor der hersker udbredt ligegyldighed over for etablerede religiøse organisationer og deres praksis.

Den grundige gennemgang af magtkampene om den danske folkekirke, mellem kirken og den danske stat såvel som mellem kirken og andre religiøse organisationer er dog, for mig at se, ikke den mest spændende del af Lene Kühles afhandling. Hvad der klarest adskiller hendes arbejde fra andre religionssociologers, er, at hun insisterer på at placere disse magtkampe $i$ et teoretisk perspektiv og dermed forjætter en belysning af magt på et mere generelt niveau. Hun karakteriserer således afhandlingens tilgang som et "systematically empirical attempt to do theory" (s. 2). Dette er en 'kodet' vending, som varskoer hendes læsere om den brug, som hun efterfølgende gør af nogle af Pierre Bourdieus ukonventionelle ideer om teori og praksis.

Udgangspunktet for Lene Kühles analyse af magt er Bourdieus påstand om, at magt aldrig er abstrakt, men altid agerer i samspillet mellem 'virkelige' menneskelige aktører og 'virkelige' sociale strukturer. Dette betyder for Bourdieu, at sociologisk analyse bør fokusere på specifikke felter, hvor magt udøves og bekæmpes. Det særlige ved hvert felt er den form, som den sociale, kulturelle eller symbolske kapital, der kæmpes om, kan have. Magthaverne i felt kan derudover forsøge at rationalisere, legitimere og forsvare deres position ved at udøve 'symbolsk vold' på en sådan måde, at de ved at mystificere og forvirre underordnede grupper kan kontrollere disse. Et af resultaterne af denne ærlig talt noget deterministiske - magtforståelse er opfattelsen af, at 'kulturel reproduktion’ opnås gennem indprentningen af 'habitus' eller indlærte dispositioner for at tænke, føle og handle på bestemte måder. Habitus er både et resultat af sociale og kulturelle strukturer og en kraft, som potentielt kan restrukturere social handling.

Hvis vi ser bort fra de mange, forskelligartede kritikpunkter, der er blevet rejst mod Bourdieus begrebsapparat, ${ }^{3}$ ligger min interesse primært i den kreative brug, som Lene Kühle gør af udvalgte Bourdieuske begreber. Det gælder i særdeleshed det centrale argument $\mathrm{i}$ hendes afhandling: nemlig at religion i nyere dansk historie har udviklet sig

\footnotetext{
${ }^{2}$ Fx Yinger 1946; Harrison 1959; Maduro 1982; McGuire 1983; Beckford 1983; Pickering 1985; Jacobs 1991; Ozorak 1996

${ }^{3}$ Jenkins 2002 rummer den bedste sammenfatning af kritikpunkterne.
} 
til at være et relativt autonomt felt, og at religiøs pluralisme er et trin i udviklingen af magtkampe i dette felt. Denne dristige strategi gør Lene Kühle i stand til at hæve sig over de rent filosofiske og teologiske diskussioner om pluralisme ved at stadfæste dem $\mathrm{i}$ magtrelationer mellem konkurrerende grupper og organisationer. Pluralisme er derfor forskellig fra mangfoldighed ('diversity'; Beckford 2003, 73-102). Pluralisme drejer sig om konkurrence og strid om den kapital, som karakteriserer religion.

Det forekommer mig, at denne begrebsmæssige strategi for at 'indramme' pluralisme som en særlig form for magtkamp har meget for sig, og at den minder om Jean Séguys kendte undersøgelse af de konflikter, som omgav den økumeniske bevægelse i Frankrig i 1960'erne. Lene Kühles afhandling leverer endvidere et forsøg på at forklare udviklingen af religiøse pluralisme i Danmark i form af de relationer, som udvikler sig mellem staten, folkekirken og andre religiøse organer. Kirkehistorikere kan naturligvis hænge sig i nogle af detaljerne i hendes analyser; men hun giver en overbevisende sociologisk beskrivelse af fremkomsten af religiøs pluralisme i Danmark. Hendes undersøgelse af danske fængselspræster er en interessant påvisning af, hvor langt fremskreden udviklingen af religiøs pluralisme er i fængsler sammenlignet med andre dele af det danske samfund.

\section{Hinsides Bourdieu}

Det er modigt af en ph.d.-kandidat at tilpasse en kontroversiel, sociologisk teori som Bourdieu til sit eget projekt. Lene Kühles strategi er sandelig dristig. Spørgsmålet er imidlertid, når man opvejer fordele og ulemper, om hendes strategi er passende for opgaven med at forklare fremkomsten af religiøs pluralisme som et religiøst magtfelt $\mathrm{i}$ Danmark. Mit generelle svar er, at hendes afhandling utvivlsomt er lykkedes i forhold til at identificere de forskellige faktorer, der har formet den særlige, danske form for religiøs pluralisme som udfaldet af magtkampe. Dette er stor præstation, og jeg håber, at den vil inspirere andre forskere til igen at se på religiøs pluralisme som udgangspunkt for konfliktfyldte magtkampe.

Mit næste spørgsmål er sværere. I hvilket omfang er de Bourdieuske begreber om kapital, felt og habitus uundværlige for forståelsen af religiøs pluralisme i Danmark? Der er ikke her plads til en udfoldet redegørelse for mine forbehold over for Bourdieus begreber; men jeg tror, at de er af en noget tvivlsom værdi. På den ene side kan religionssociologer drage stor nytte af Bourdieus eksempel, når de skal udføre empiriske undersøgelser af religion som et konfliktområde. Orienteringen mod spændinger, konkurrence og konflikt er essentiel for en dækkende forståelse af religion. Ikke desto mindre er det tvivlsomt, om Bourdieus mere specifikke påstande om religion er tilsvarende nyttige. Jeg vil give tre grunde til min skepsis.

For det første er Bourdieu ikke tilstrækkelig radikal i forestillingen om 'det religiøse felt'. Der er, så vidt jeg kan se, kun begrænset konsensus blandt forskere og udøvere om, hvad der gælder som religion. Det er en social konstruktion, som er under konstant konstruktion og kritik. Konsekvensen er, at det er tvivlsomt, hvorvidt det religiøse felt uproblematisk kan indgå som et analytisk begreb i religionssociologien. Endvidere er 
selve begrebet om et religiøst felt for abstrakt og for ufleksibelt til at være analytisk fordelagtigt. Det tager ikke hensyn til, at fra et sociologisk synspunkt forfølger religiøse organisationer ikke blot religiøs, men også politisk, økonomisk, kulturel og social kapital. Det er derfor ikke specielt produktivt at forstå religion som et særligt felt med en egen, karakteristisk kapital, adskilt fra andre dele af livet.

For det andet kunne en mere radikal strategi end Bourdieus være at tænke religion som et sæt af ressourcer, som kan benyttes for forskellige formål, hvoraf mange involverer magtkampe. For eksempel kan statens tvangsmæssige institutioner (militæret og fængslerne), sundhedssystemet, uddannelsessystemet og endda nogle profitsøgende virksomheder trække på religiøse ressourcer til deres specielle formål. Den kontrol, der udøves over brugen af religiøse ressourcer, varierer i henseende til sted og tid og i forhold til den ene og den anden religion. Religiøs pluralisme af den type, der er opstået i Danmark, er det særlige udfald af langvarige kampe om kontrollen over, hvad der er tilladeligt i religionens navn. Begrebet om det religiøse felt er alt for konservativt for $\mathrm{mig}$, fordi det uden ordentlig begrundelse implicerer enighed om, hvad religion betyder og hvilken plads den skal have i samfundet - det vil sige i sit eget felt. Et mere radikalt udgangspunkt ville være at undersøge de konfliktfyldte konstruktioner af religionens betydning i fx retssale, fængsler, medier og skoler (Beckford 1999).

For det tredje er jeg ikke overrasket over, at det konkluderende kapitel i Lene Kühles afhandling anerkender, at det ikke har været muligt fuldt at yde hele Bourdieus begrebsmæssige apparat retfærdighed. Hun foreslår beskedent, at det ville være for omfattende at gøre $i$ en afhandling. Min vurdering er mere kritisk i forhold til Bourdieu. Jeg tvivler på, at hans forståelse af religion (andet end måske i relation til en hierarkisk organisation som den katolske kirke) er god nok til at fungere som basis for andre sociologiske undersøgelser af religion. Det er sigende, at det konkluderende kapitel i afhandlingen, der resumerer afhandlingens hovedpunkter og som introducerer nogle fascinerende sammenligninger mellem præster i fængsler, militæret, sundhedsvæsnet og universiteterne, gør dette med kun få referencer til Bourdieu. I stedet bliver spørgsmålet om pluralisme stillet i relation til de konkurrerende gruppers interesser. Begreberne om kapital, felt og habitus er som sunket i jorden. Faktisk passer iagttagelsen af, at "religious diversity is handled in quite distinctive ways in different parts of Danish society"(s. 263), dårligt med forestillingen om et religiøst felt.

Som en konklusion kan man sige, at Pierre Bourdieus begrebsapparat er et nyttigt redskab i den forstand, at det retter sociologers opmærksomhed mod de magtkampe, som er centrale for social aktivitet. Den Bourdieuske tilgang er også nyttig i det omfang, den kan medvirke til at undgå de værste former for determinisme uden at overgå til en ubegrænset voluntarisme. Men Bourdieus forståelse af religion hviler for tungt og for eksklusivt på hans viden om den romersk-katolske kirke i Frankrig og viser for lidt forståelse for mindre hierarkiske og mindre gejstlige former for religion. Jeg må simpelthen afvise hans påstand om, at "religion has been dissolved into a field of larger symbolic manipulation" (Bourdieu 1987, 121). Endvidere er hans forestilling om religiøs kapital, religiøst felt og religiøs habitus for ufleksible til at fange den kompleksitet 
og underfundighed, som karakteriserer nutidens religion, såvel som de kræfter, der forsøger at kontrollere den i det offentlige liv. Magt og konflikt er med nødvendighed centrale for sociologiske undersøgelser af religion. Det er derimod ikke nødvendigt at begrænse religion analytisk til specifikke former for kapital, felter eller habitus.

\section{Litteratur}

BECKFORD, J.A.

1983 "The restoration of 'power' to the sociology of religion", Sociological Analysis 44 (1), 11-31.

1999 "The politics of defining religion in secular society: from a taken-for-granted institution to a contested resource", in: J.G. Platvoet \& A.L. Molendijk, eds., The Pragmatics of Defining Religion: Contexts, Concepts and Conflicts, E.J. Brill, Leiden, 23-40.

2003 Social Theory and Religion, Cambridge University Press, Cambridge.

BOURDIEU, P.

1987 Choses dites, Les Editions de Minuit, Paris.

FERRARI, S.

1999 "Le droit européen en matière religieuse et ses conséquences pour les sectes", in: F. Champion \& M. Cohen, eds., Sectes et Démocratie, Seuil, Paris, 359-72.

HARRISON, P. M.

1959 Authority and Power in the Free Church Tradition, Southern Illinois University Press, Carbondale, IL.

JACOBS, J.L.

1991 "Gender and power in new religious movements. A feminist discourse on the scientific study of religion", Religion 21 (4), 345-56.

JENKINS, R.

2002 Pierre Bourdieu, Routledge, London.

LEFORT, C.

1986 Essais sur le politique: XIXe-XXe siècles, Seuil, Paris.

MADURO, O.

1982 Religion and Social Conflicts, Orbis, Maryknoll, NY.

MCGUIRE, M.

1983 "Words of power: personal empowerment and healing", Culture, Medicine and Psychiatry 7 (2), 21-40.

OZORAK, E.W.

1996 "The power, but not the glory: how women empower themselves through religion", Journal for the Scientific Study of Religion 35 (1), 17-29.

PICKERING, W.S.F.

1985 "Protestantism and power: some sociological observations", Social Compass 32 (2-3), 163-74.

SÉGUY, J.

1973 Les Conflits du Dialogue, Cerf, Paris.

Willaime, J.-P.

Under udgivelse "Religion in ultramodernity", in: J.A. Beckford \& J. Walliss, eds., Theorising Religion: Classical and Contemporary Debates, Ashgate, Aldershot, 74-86. 
YINGER, J.M.

1946 Religion in the Struggle for Power, Duke University Press, Durham, NC. 